\section{(Re-)construing Space as Capital: Contributions from a Study with Local Entrepreneurs}

\author{
Anderson de Souza Sant'Anna ${ }^{\dagger}$ \\ Fundação Dom Cabral (FDC) \\ Daniela Martins Diniz ${ }^{\Omega}$ \\ Universidade Federal de Minas Gerais - UFMG
}

\section{ABSTRACT}

Taking as reference the approaches adopted by Bourdieu (2010) and Jacobs (2011), the focus of this article is to present the findings of a research effort designed to investigate the relationships between the constructs Space and Social Dynamics. In this sense, it seeks to investigate in which manner did the relationships among different social agents - emphasizing the roles played by local entrepreneurs - which, upon mobilizing different capitals - economic, social, cultural and symbolic (BOURDIEU, 2010) - shape and are shaped by specific spatial configurations, creators of socio-spatial dynamics that are diversity-enablers to a greater or lesser extent (JACOBS, 2011). For this purpose, an investigation inspired on the Grounded Theory was undertaken, involving documentary analysis, direct observation and 41 semi-structured interviews with entrepreneurs, dwellers, passers-by and opinion leaders inserted into the dynamics of an important peripheral street in the city of Sete Lagoas/ MG. Notable findings include the relevance of studies that draw more systematic considerations, extrapolating economic, social, cultural and symbolic capitals (BOURDIEU, 2010), allocating a greater importance to "spatial capital", usually relegated to a secondary plane not only in Bourdieu's "Theory of Practical Action" as well as in classical studies into Economics and Geography (SANTOS, 2012). Another of this study's significant findings is that the subjects personified in the different types of entrepreneurs identified - Traditional, Modern and Bricoleurs - do not emerge nor act in a socio-spatial void, nor are independent from each other. Quite the opposite, they are a part of a community social ecology (HANNAN; FREEMAN, 1984), rife with dispute, collaboration and intentional and unconscious synergies, in which space, in addition to technological-economical forces, plays a relevant role.

Keywords: Community entrepreneurship, Space, Socio-spatial dynamics, Theory of practical action.

\section{INTRODUCTION}

The relevance of investigating the street as a for a more trustworthy understanding of the contemporary urban everyday life and the social interaction among its different social agents has been showing itself with increasing vitality in administrative and organizational studies (SANTOS, 2012; JACOBS, 2011; BOURDIEU, 2010). Through this
Corresponding author:

† Fundação Dom Cabral (FDC).

E-mail: danidiniz09@yahoo.com.br

${ }^{\Omega}$ Universidade Federal de Minas Gerais

- UFMG

E-mail: danidiniz09@yahoo.com.br

Received: 05/16/2016. Revised: 08/24/2016. Accepted: 08/24/2016.

Published Online: 07/01/2017.

DOI: http://dx.doi.org/10.15728/bbr.2017.14.5.6 
viewpoint, the street emerges as a fundamental space to observe the dynamics ruled by an increasingly flexible accumulation regime (HARVEY, 1989). It is in it - and less so in conventional organizations - that the observer may capture, observe and analyze the diversity and plurality of life in today's societies, representing the locus in which the ensemble of its agents share its singularities (JACOBS, 2011).

According to Cordeiro (2008,p. 9) the street presents itself as an "[...] empirical frame that allows finding a multiplicity of viewpoints and objects, an ethnographic frame affording the exploration and understanding of contemporary live.". Adding to this statement, Da Matta (1997) surmised that the analysis of socio-spatial processes strongly takes on relational perspectives capable of different reality readings and constructions.

At any rate, the street has been under different interpretation lenses, including its study as a "cultural device" (AGIER, 2011), as a "space of diversity and vitality" (JACOBS, 2009), as a "political arena" (MINTZBERG, 2006), as a "field of disputes" (BOURDIEU, 2010), and furthermore becoming a favored "heterotopia" for the observation and analysis of relational phenomena that are a highlight of contemporaneousness.

Pierre Bourdieu's contributions to sociology are, in this sense, paradigmatic, particularly by allowing concrete elements factored into the understanding of such spatialities such as fight games and interactions, enabling the demonstration of the manner by which relationships among different agents contribute towards the production of diversity, innovation and change contexts. This to the extent that the cities' and their myriad places and dynamics' production is intrinsically related to the (re-)production of discourses, relationships and social practices. Through these lenses, Bourdieu's $(2009,2010)$ theoretical framework offers significant devices for the understanding of the strife arenas into which such agents are inserted and how each one of them mobilizes different capitals seeking to ensure a distinctive place in a given social field.

In addition, it is well to consider Jane Jacobs' anticipatory perspective by suggesting, in the 1960s, that it is via the street that a society's life and plurality can be better investigated. Because it is a place of passage, circulation and also of street corners, talks, violence, understanding, eroticism, diversity and, therefore, of sociability and construction of civilization; it is in the street space that contemporary social relations effectively happen (JACOBS, 1969).

The approaches of these two authors - Bourdieu (2010) and Jacobs (2011) taken as reference a posteriori, of this article is to present the findings of a research effort designed to investigate the relationships between the constructs Space and Social Dynamics. In this sense, it seeks to investigate in which manner did the relationships among different social agents - in this specific case emphasizing local entrepreneurs - which, upon mobilizing different capitals - economic, social, cultural and symbolic (BOURDIEU, 2010) - shape and are shaped by specific spatial configurations, creators of socio-spatial dynamics that are diversity-enablers to a greater or lesser extent (JACOBS, 2011). In other words, authors posit that different agents, upon articulating different capitals (BOURDIEU, 2010, 2008, 1996), create different socioeconomic and spatial dynamics, enablers of diversity and vitality to a greater or lesser extent (JACOBS, 2011).

It behooves the authors to highlight that, for the purposes of this study, space emerges as a dynamic and relational category (SANTOS, 2012), comprised of an indissoluble set of systems of objects and actions, each one composed of micro spaces (SANTOS, 2014; 2014a; 1988) or in-between spaces (AGIER, 2011). Thus, a theoretical framework of diversity and vitality was used for the analysis of the objects, as proposed by Jacobs (2011). Bourdieu's (2008) "Theory of Practical Action" was employed in the investigation of the actions.

Accordingly, the core issue that prompted the pursuit of this study can be thus synthesized: in which manner do different social agents articulate among themselves and 
BBR

14,3

546

mobilize different capitals - economic, social, cultural, symbolic and spatial - seeking to produce diversity and vitality socio-spatial dynamics?

Once the research issues and question have been established, it is possible to pinpoint as the specific objectives of the investigation that were the cornerstones of this study: 1 . Describing the public space object of this investigation, considering diversity conditions as proposed by Jacobs (2011); 2. Analyze common capital mobilization forms - economic, cultural, symbolic - involved in the relations among the main social agents involved (BOURDIEU, 2010); 3. Investigate the relations between mobilized capitals and spatial diversity conditions.

In methodological terms the investigation can be characterized as being of qualitative nature, whose inspiration was the Grounded Theory method (GLASER; STRAUSS, 1967). As for the data-gathering strategy, it was based on employing multiple instruments, combining documentary analysis, direct observation and semi-structured and in-depth interviews. Rua Santa Juliana, located in the municipality of Sete Lagoas/MG was selected as the object of the investigation; this street represents an important axis for the local economic development. The choice of Rua Santa Juliana as the research unit, in addition to factors such as its importance and representativeness in the local geoeconomic structure, was due to traits that signal is diversity of uses and functions and its potential to generate socioeconomic and cultural vitality.

In terms of its theoretical contributions, the study is justified by broadening investigations into the multiplicity of inter-relations that end up by forging contemporary socio-spatial dynamics. Broadening possibilities regarding new looks and conceptual-methodological contributions that will favor the construction of urban and organizational contexts that are more adherent to diversity and vitality, core competitiveness elements in such coevality, as branded by post-industrial experience (HARVEY, 1989).

It also clearly shows potential for the application of still-scantily applied theoretical frameworks to Organizational and Urban Studies, notably in Brazil, such as Bordieu's perspective. In addition and notably, the empirical findings of this study denote the importance of spatial capital, apparently scarcely highlighted in that author's studies.

Furthermore, to the extent that territorial development is forged by a network of agents with plural interests, operating in the local and global territories as a manner to seek innovation and competitiveness, identify the characteristics of local entrepreneurs and the mechanisms employed in their manifestation in their mobilization and interaction processes with different agents involved in such processes was proven significant to a more systemic understanding of the bases for the development of policies and interventions favoring effectively sustainable local development (SANT'ANNA; NELSON, 2013; NELSON; SANT'ANNA, 2012).

In methodological terms, the main contribution from this study concerns the adoption of the research method inspired by the Grounded Theory, which essentially seeks to "let the field talk". Under the conduction of certain "floating attention", it proved significant to deal with the "field agonistics" (LATOUR, 1994) to shape, a posteriori only, a theoretical scenario (JACOBS, 2011; BOURDIEU, 2010) such as to allow the analysis of the data gathered.

In practical terms, the investigation contributes with subsidies for the development of policies and practices veered towards the construction of organizational and urban ambiances that are more favorable to diversity and vitality. Moreover, it provides elements for crafting policies and actions veered towards urban and organizational development that is more participatory and democratic, respecting the diversity and richness underlying the differences. 


\subsection{DIVERSITY AND VITALITY SPACES: JANE JACOBS' PERSPECTIVE}

Bearing in mind the objectives of this research effort, it is important to understand how cities yield a sufficient diversity of uses and functions to preserve civilization itself. According to Jacobs (2011), there are four spatial conditions of the essence to create an "exuberant" diversity in a city's districts and streets. The first condition indicates that the street should contain an array of activities such as to ensure the presence of people at different times and for different reasons, using a major part of the available infrastructure.

Besides creating safety on the streets, such variety of uses and functions, in addition to the continuous circulation, contribute to enliven local enterprises. Commercial houses, as streets, require attendees for their survival. These distinctive city use combinations are not, therefore, chaos calling for order. Quite the opposite, they represent a manner of organization so complex and highly developed as to enable the city to create diversity and keep itself alive (JACOBS, 2011).

The second condition, in turn, is related to the size of street blocks. The author proposes that most street blocks should be short in length and, therefore, provide the opportunity to cross streets. Isolated, separated neighborhoods run the risk of being abandoned. When long blocks prevail, even people dwelling in the same neighborhood tend to keep away, making it difficult to establish complex combinations of shared urban uses.

The third urban diversity requirement concerns the profile of the buildings erected on the street. For Jacobs (2011), a street should contain a combination of buildings of different ages and repair, and also include a fair percentage of older buildings, such as to yield diverse economic income. Therefore, streets require a mix of new and older buildings to cultivate the blend of diversity. If a city area only has new buildings, this city's ventures will be limited to those who can bear the high costs of these new buildings. Therefore, this is a factor that limits diversity, since neighborhood bars and typical restaurants, for example, may not have the conditions to install in newly-built buildings (JACOBS, 2011).

Finally, the fourth condition is related to the flow of individuals. Jacobs (2011) surmises that the street should contemplate a sufficiently high density of people, whatever their pursuits may be, including a broad concentration of dwellers. In addition to dwellers, the author stresses the importance of the presence of unknown agents who work or circulate in the region, for their contribution to local diversity. A dense flow of people is, therefore, considered to be a positive aspect, to the extent that it represents a source of vitality and a wealth of differences and options.

In summary, for a street or neighborhood to contain such "exuberant" diversity, that is, the capacity to unite the most different preferences, abilities, requirements in a same region, it is necessary that it contains a high density of people in circulation, day and night, a mix of new and older buildings that shelter myriad services, and also short street blocks to facilitate the circulation of people.

\subsection{ARTICULATING MULTIPLE AGENTS AND DIFFERENT CAPITALS: CONTRIBUTIONS FROM BOURDIEU'S SOCIOLOGY}

Bourdieu's "Theory of Practical Action" was chosen a posteriori as the theoretical framework for the analysis of relations among the social agents involved in the investigated street dynamics, notably his notions of Habitus, Field, Capital and Distinction. 
BBR

14,3

Overall, one of the main concepts proposed by Bourdieu (2004) is the notion of habitus, construed as a system of dispositions acquired by experience and through socialization processes, which vary by place and time. It concerns, therefore, manners of acting, doing, perceiving, feeling and thinking, interiorized as the outcome of its existence conditions:

Conditionings associated to a particular class of existence conditions create habitus, systems of durable and transposable, structured structures predisposed to operate as structuring structures, that is, as practice and representation creating and organizing principles that can be objectively adapted to their objective without assuming a conscious intention of purpose and the express command of operations required to achieve them (BOURDIEU, 2009, p. 87).

Together with habitus, the field concept takes on an outstanding place in his "Theory of Practical Action". As a multidimensional space, the field cannot be treated simply for its economic dimension; the symbolic struggles happening within it (BOURDIEU, 2010) must also be considered. In this sense, for Bourdieu, society must be understood as a set of social fields crisscrossed by struggles among clusters. Each field is therefore marked by social agents prompted by the same habitus, and the relation between habitus and field is one of conditioning: the field structures the habitus. Bourdieu (2010) sought to synthesize the notion of field as:

[...] a multidimensional space of positions such that any current position can be defined as a function of a multidimensional system of coordinates whose values correspond to the values of the different applicable variables: the agents are thus scattered through it, in the first dimension according to the global volume of capital they amass and, in the second dimension according to their capital make-up - that is, according to the relative weight of the different species in the ensemble of the two possessions (BOURDIEU, 2010, p. 135).

That is, each element in the field is an agent who shares similar interests and capitals. Therefore, the fields are hierarchically organized as of capitals, power and domination symbols. In other words, the different forms of capital enable social space structuring. Thus, to understand how such space is organized, an analysis of the different types of mobilized capitals becomes relevant.

Differently from Karl Marx, Bourdieu (2010) did not limit the concept of capital to the economic dimension, but splits it into four types: economic, cultural, social and symbolic. Economic capital is comprised of the different production factors and by the set of economic goods, such as material goods, income and property. Cultural capital, in turn, corresponds to the set of understandings and intellectual qualifications conveyed by families and educational institutions throughout the individual's lifetime. Social capital involves the maintenance of the social relations network that includes individuals and the collectiveness, accumulated through a socialization process (BOURDIEU, 2009).

Last is symbolic capital, which refers to the other capitals and is associated to them to the extent that it does not stand alone nor is independent from the others in value-adding. It is related to the accumulation of prestige and social recognition by the individual or group that preserves under his or its command the resources deemed essential in a specific field.

To the extent that the struggle within a given field is motivated by the wish to accumulate symbolic capital, the field incorporates a symbolic dimension (BOURDIEU, 2010), in addition to being a social space for conflicts and negotiation. It is therefore organized according to the rationale of differences, that is, of a distinctive trait of a certain quality which only exists vis-àvis other properties. Individuals of a given field seek to differentiate themselves and preserve 
their own social identity, either through their family names, their professions, ownership of goods, the office they occupy, institutions they are related to, among other means.

\section{METHODOLOGY}

Considering the lack in Brazil of investigations similar to this and the assumption that the adoption of more positivistic methodologies would bring along the risk to unduly impose rationales or categories from one field or social context upon another, hiding observations that could escape consolidated theoretical frameworks, (DEY, 2007; LINCOLN; GUBA, 1985), the authors opted for conducting a qualitative study inspired upon the Grounded Theory (GLASER, 1992, 1978; GLASER; STRAUSS, 1967).

Originally conceived by Glaser and Strauss (1967), the Grounded Theory method achieved comprehensive application in qualitative research work referring to theoretical development induced by the analysis of empirical data through the case perspective, instead of the approach centered on previously established theoretical models and categories (STRAUSS, 1987; STRAUSS; CORBIN, 1990; GLASER, 1992; BRYMAN, 2001).

Differently from more conventional methods that seek the description of a given situation vis-à-vis a theoretical model defined a priori, in the Grounded Theory the objective resides in its contribution towards the formulation of new categories. Along with the collection, codification and analysis of the gathered data, the development of the empirical survey in itself suggests what will the investigation subjects be, where to find them, and what are the aspects to be analyzed. The definition of the research subjects is, therefore, a continuous process, which ends when the categories created are established and validated (theoretical saturation).

Basing on such characteristics, this investigation was based on the use of multiple instruments: documentary analysis, direct observation - involving 15 in loco visits to the street - and 41 semi-structured interviews. Firstly, during the documentary analysis stage, the authors sought to describe the street, its history, dwellers, ventures, articulations with other streets, adjoining neighborhoods and with the city as a whole and local leaders, in addition to its current situation and challenges for the future.

As concerns the interviews, the target audience involved passers-by, entrepreneurs, workers and dwellers of Rua Santa Juliana and adjoining neighborhoods. The interviews were held in the period between August 2014 and December 2015 and yielded 2,500 tape minutes, transcribed into more than 350 pages.

The content analysis by category method (BARDIN, 2014; RICHARDSON, 1985) was chose to treat the data gathered via interviews. This procedure consists in employing content systematization, interpretation and description of the information gathered, such as to understand the discourse, deepen its characteristics and extract the most important details. Therefore, it was possible to examine different dimensions contained in the respondent reports and build inferences from them. To facilitate this stage, analytical category were created basing on literature and reviewed under the light of the evidence contained in this research effort.

In addition to a careful manual analysis of the data gathered from each interview, the data were examined using the NVivo 8.0 qualitative data treatment software, following the codification and categorization procedure as indicated by Flick (2009).

\section{DATA PRESENTATION AND ANALYSIS}

\subsection{VITALITY-YIELDING CONDITIONS}

In this topic the authors seek to analyze the Rua Santa Juliana urban space, aiming at identifying the four diversity conditions as per the studies conducted by Jacobs (2011): 1. Diversity of functions; 2. Size of street blocks; 3. Mix of new and older buildings; 4. Density of people. 
BBR

14,3

Findings unveiled a broad diversity of uses and functions. As concerns commercial diversity, notably Rua Santa Juliana shelters ventures relating to different walks of activity. Bars and restaurants, local and national supermarket chains, franchises, dealerships, automobile and auto parts stores, banking branch, lottery house, pharmacies and construction material depots are a few of the activities conducted in the region. Add to that myriad informal ventures - peddlers, hucksters, household service providers - who operate on the street. Interview data highlight that this diversity has increased since the implementation of large companies in the region, such as Iveco-Fiat and Ambev.

In addition to the growing number of commercial establishments and their diversification, reports indicate a substantial improvement in the quality of the products and services offered. For a significant number of respondents these changes are directly associated to changes in consumer profiles, mainly by the incorporation of the preferences and habitus of professionals from large corporations installed in the region, commonly described as more sophisticated and demanding.

By way of consequence, they noted the fact that a substantial number of traditional commercial establishments have been compelled to adapt to market changes, incorporating initiatives targeted at a greater professionalization of their ventures, including better selection and capacity-building of their professionals.

Several respondents noted that, while 10 or 15 years ago Rua Santa Juliana was but a passage street affording access from the rural area to the urban area of Sete Lagoas, it today represents one of its major commercial venues, competing against the traditional commerce found in the city's downtown area:

There's no gain by going downtown. People from neighboring cities are coming to this region to buy. I have customers who buy from me at this store and don't go to the downtown store any more (INTERVIEW 1).

Commercial expansion, however, has caused a growing movement in the street's real estate sector, with older homes being wrecked down or transformed into commercial stores. Besides creating some amazement with old time city dwellers, this trend is pinpointed as harmful to local diversity. As Jacobs (2009) indicated, it is of the essence that there is a high concentration of people whose purpose is to live there. Therefore, in order that Rua Santa Juliana does not become a thoroughfare - a mere passageway - reports indicate that it is imperative that commerce be more harmoniously combined with the residential function:

I think commerce is growing a lot [...] Growing more and more. [...] The street is becoming a corridor with each passing day, and they're building urban developments near Iveco. You hardly see residences on Santa Juliana anymore and I think this is the trend: to keep growing and people increasingly seeking to come here. (INTERVIEW 4).

The diversity of uses and functions is also directly related to the plurality of the street's users, according to Jacobs (2011). As concerns this item, Rua Santa Juliana is, again, an exemplary case. The greater contingent of the street's users being from buffer zone neighborhoods notwithstanding - and mainly from families within the " $C$ " and " $D$ " economic classes - the types of buyers seeking the street's commerce has diversified, including representatives from the rural area closer to the street, from small neighboring towns, popular neighborhoods and low-income housing projects, in addition to professionals from large companies installed in the buffer zone and residing in medium and high class condominiums. 
Another indicator of street diversity, according to Jacobs (2011) is the street block size. She surmises that most street blocks should be short, affording frequent opportunities to go around corners. In general, the data collected from Rua Santa Juliana comply with this item, notably in its stretch of greatest commercial vitality. The conveniences ensuing from the small size of the city blocks notwithstanding, reports gathered unveiled that the circulation of people along the street is impacted by other factors, such as unpaved sidewalks, narrow sidewalks, the unfair competition for "space" - on the sidewalks, even - from vehicles, bicycles, motorcycles, buses and trucks. Add complaints because of the quick and inordinate growth of vehicle and bus traffic, without the corresponding improvements in the region's mobility:

As concerns these two aspects, there are no parking spots on Rua Santa Juliana, traffic is quite difficult, very heavy, and sidewalks in many stretches are very narrow. [...] Chaotic. (INTERVIEW 27).

As for the mix between new and older buildings, Jacobs (2011) remarks that the street should contain a mix of buildings of different ages and conditions of repair. Such condition can also be seen on Rua Santa Juliana. In this sense, an aspect that begs attention is that the street's and its properties' - homes or commercial outfits - layout and structure do not follow a single architectural and construction pattern. Such unique combinations bring life to the place. Therefore, the street has the capacity to offer something to different audiences, confirming Jacobs' (2011) assumption. It is a mix of homes and older buildings and newer buildings specially erected after the installation of large corporations.

Respondents unanimously feel that Rua Santa Juliana contemplates the condition relating to the diversity of people: a high density of individuals at different times pursuing myriad purposes (dwellers, strangers, people who work or walk at the place). This intense circulation contributes to local diversity and safety (JACOBS, 2011):

This street is a traffic corridor to many neighborhoods in this region. Lots of people going to work riding bikes, motorbikes and buses. Then there's packed traffic peaking in the morning, and lots of buses in the afternoon. The whole day. Even at night. Street is pretty busy until 10 PM. There's bars and diners. (INTERVIEW 3).

Problems and limitations notwithstanding, the data set proves significant not only for empirically corroborating Rua Santa Juliana's vitality conditions (JACOBS, 2011), but, above all, for highlighting the pre-eminent role of "space" and a protagonist element of economic, cultural and social vitality. Such landscape became evident in the respondents' denial of views that still insist in characterizing the space as "dead" or just as a "frame" on which social relations occur (SANTOS, 2012). Conversely, data indicate their relevance and prominent role as "capital" mobilized by the investigated social agents in different strategies veered towards dominance of the field in which they are inserted.

\subsection{INTERACTIONS AMONG SOCIAL AGENTS: ENTREPRENEURS AS PROTAGONISTS}

The analysis of the relations among different social agents present in the Rua Santa Juliana spatial dynamics unveiled tensions and contradictions associated with three core themes: 1. Among geographical areas of the city: downtown vs. periphery; 2 . In the relations among local entrepreneurs and remaining social agents involved in the street dynamics; 3 . In the business models and spatial distributions of local ventures: new and old (Table 1). 
Table 1. Local entrepreneurs: main attributes

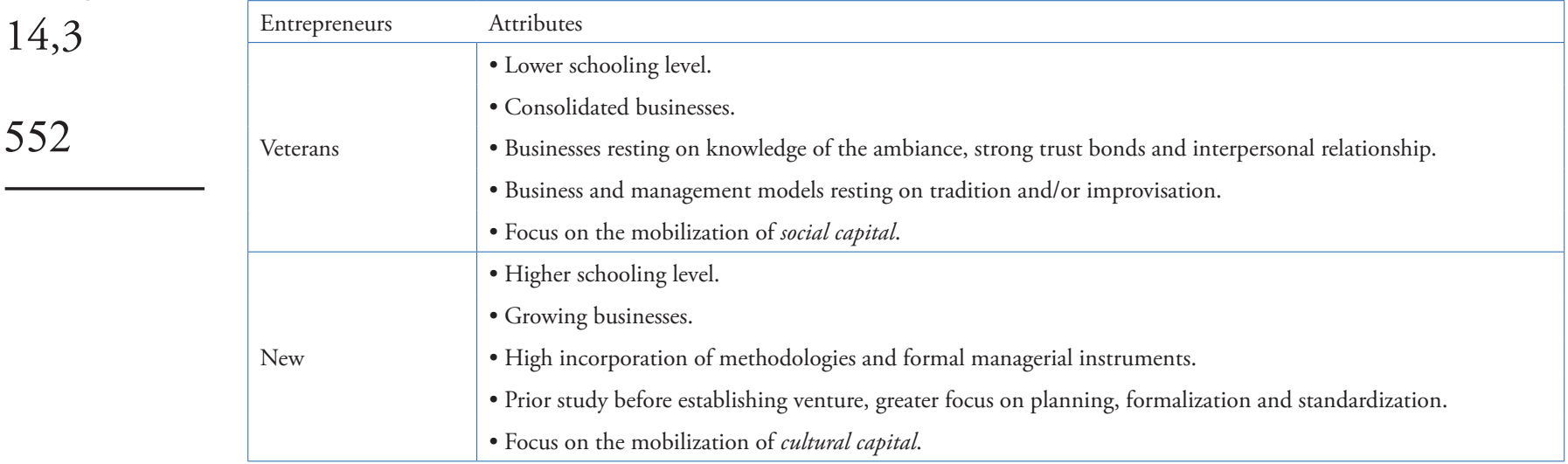

Source: Prepared by the authors

In this sense, the protagonist nature of the local entrepreneurs in the local socioeconomic and spatial dynamics dominance became evident. Therefore the authors will seek to emphasize the role of these agents in the analyses already defined.

At any rate, such protagonism notwithstanding, the entrepreneurs of Rua Santa Juliana cannot be described as a monolithic cluster. Quite the opposite, considering the different capitals they mobilize - economic, social, cultural and symbolic (Bourdieu, 2010) - it was possible to differentiate them into three clusters: Traditional Entrepreneurs, Modern Entrepreneurs and Bricoleur Entrepreneurs (Table 2).

Table 2. Rua Santa Juliana: clusters of entrepreneurs per habitus

\begin{tabular}{|ll|}
\hline Clusters & Habitus \\
\hline Traditional Entrepreneurs & Simplicity, tacit knowledge, modesty, family, conservatism. \\
\hline Modern Entrepreneurs & Entertainment, short run, profit, competitiveness, financial results, growth, diversification. \\
\hline Bricoleur Entrepreneurs & Improvisation, informality, copying, the "Brazilian fix", sense of opportunity, adventure, risk, adaptability. \\
\hline
\end{tabular}

Source: Prepared by the authors

As far as distinctive capitals of each one of these clusters are concerned - Traditional, Modern and Bricoleur - notably, while Traditional Entrepreneurs denote a strong connection to their family names and a strong emotional connection to the place, Modern Entrepreneurs can be described by the quest for results and by the adoption of business rationales centered upon more modern management techniques. They are described as short run-, profit-focused.

In addition, Traditional Entrepreneurs seek advantages and manners of differentiation by mobilizing more traditionally-based capitals, including their knowledge of the place and its consumer market, interpersonal and trust relations and strong emotional bonds with the community (BOURDIEU, 2008). Modern Entrepreneurs, in turn, seek to mobilize cultural and intellectual capitals, and are notable for their adoption of new technologies and management models and for their emphasis on discourses preconizing personal openness to constant change and adaptations, flexibilization of processes, patterns and standards as originally designed and adequacy to [...] the local market's culture.

Finally, a strong presence of Bricoleur Entrepreneurs is observed, who prioritize attributes of improvisation, sense of opportunity and adaptability. They are represented by small vegetable stands, improvised taverns, trendy product kiosks, typically informal commerce, commerce imitating other, more consolidated ventures, and some such. LéviStrauss (1970) surmises that the bricoleur does not operate according to a previouslydefined plan; rather, he operates by devising structures according to the elements at hand: 
These elements are, therefore, partially particular: enough such that the bricoleur does not require the equipment and knowledge of all bodies of management; but insufficient for each element to subjected to precise, specific employment. Each element represents a set of relations at the same time concrete and virtual; they are operators, however usable as a function of any operation within a type (LÉVI-STRAUSS, 1970, p. 39).

The distribution analysis of local entrepreneurs in the applied typology unveils the prevalence of Traditional Entrepreneurs (56\%) followed by Bricoleurs (38\%) and Modern (6\%) (Table 3).

\begin{tabular}{lc}
$\begin{array}{l}\text { Table 3. Rua Santa Juliana: percentage of entrepreneurs by } \\
\text { cluster }\end{array}$ \\
\hline Cluster of Entrepreneurs & $\%$ \\
\hline Traditional Entrepreneurs & 56 \\
Modern Entrepreneurs & 6 \\
Bricoleur Entrepreneurs & 38 \\
\hline
\end{tabular}

Source: Prepared by the authors

Another significant finding concerns the possibility of considering the entrepreneurs operating out of Rua Santa Juliana from their position in the street's geographic space. Through this perspective, four main stretches can be identified, which define the street: Residential, Services, Commerce, and Major Ventures (Figure 1).

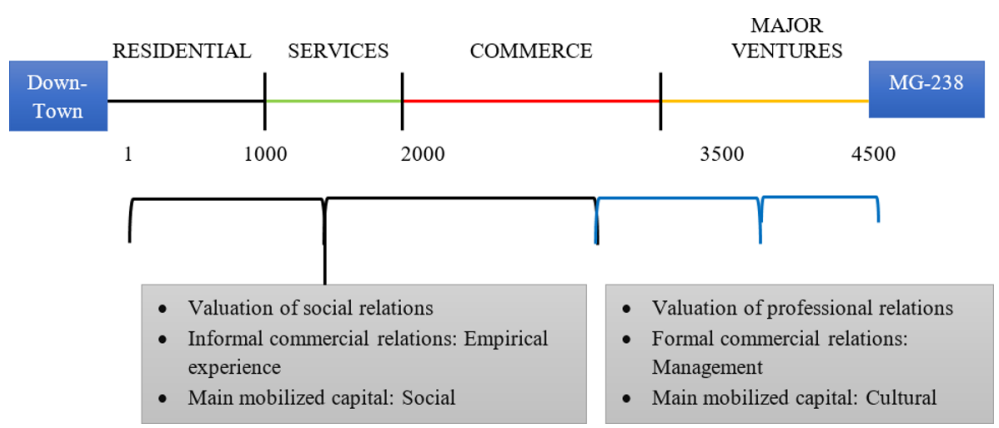

Figure 1. Entrepreneurs according to their spatial location

Source: Prepared by the authors.

Residential properties prevail in the first stretch of the street, with a few scattered commercial establishments. In the second stretch service, recreation and leisure establishments prevail. There is a massive presence of taverns, bars, and restaurants, most of them belonging to Traditional and Bricoleur Entrepreneurs. Management models found in these establishments are scarcely systematic, include strong informality traits and are broadly founded upon trust bonds.

As concerns the third stretch, shorter blocks prevail; that, in addition to the high population density of the neighborhoods that comprise the street's buffer zone are a few of the factors that favor a greater concentration of commercial ventures. The "swelling" of adjoining neighborhoods by workers from the large corporations installed in the region enabled its quick valuation for commercial or mixed purposes - commerce and residence. This stretch contains the greatest mix of entrepreneurs - Traditional, Modern and Bricoleur Entrepreneurs - in addition to the existence of two-story houses, in which a commercial establishment operates on the ground floor while the upper floor is designed for residential purposes. 
BBR

14,3
The last stretch, where the street ends, is characterized by the prevalence of larger ventures, which require more physical space, such as supermarket, car dealerships, large construction materials retail stores, and construction equipment rental stores. Modern Ventures prevail on this stretch. Figure 2 presents an overall view of the different clusters of entrepreneurs present on the stretches that characterize Rua Santa Juliana.

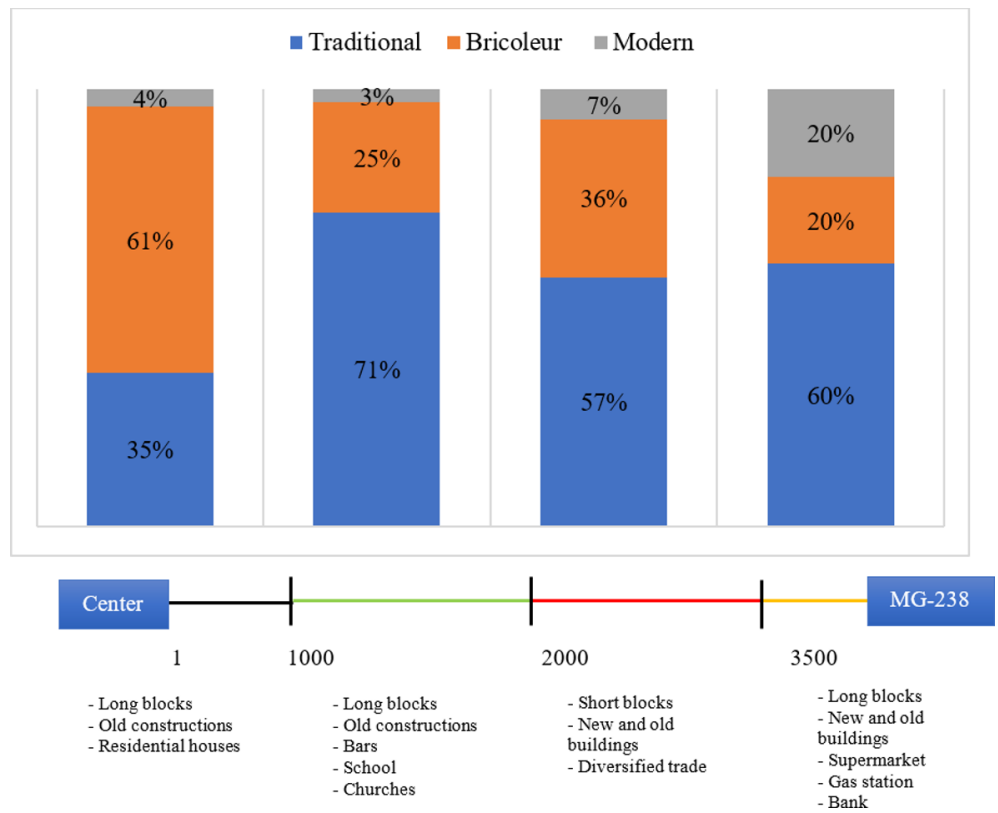

Figure 2. Rua Santa Juliana: percentage of clusters of entrepreneurs per stretch Traditional Bricoleur Modern

Source: Prepared by the authors.

Testimonies collected, including entrepreneurs, unveil de complementarity of capitals between older and new merchants - and, among these, traditional, modern and bricoleur entrepreneurs - as a prevailing factor in public improvements incorporated to the street, along the past two decades. According to reports, the well-articulated combination between symbolic and social capitals contributed by older merchants and economic and cultural capitals contributed by new entrants have proven significant for the street's development.

They also point out that, despite the high attractiveness of Rua Santa Juliana to new entrepreneurs, the existing ones do not report any fiercer competition among them. The discourse of healthy competition, of mutual help, complementarity, and competition against the city's downtown, not among them is recurrent.

In summary, the findings from this study are relevant, moreover to the extent that they indicate the relevance of more systematic considerations extrapolating economic, social, cultural and symbolic capitals (BOURDIEU, 2008, 2010), allocating a greater importance to "spatial" capital, usually relegated to a second plane by classic Economics and Geography studies (SANTOS, 2012).

\section{FINAL CONSIDERATIONS}

The current relevance attributed to the spatial dimension becomes evident by the growing interest dedicated to it not only by geographers, urbanists, and planners but also by sociologists, historians, ethnologists, and demographers. Such interest is associated to the contemporary globalization processes of the economy and markets, which imply requirements for redefinition of concepts such as local and happening, and for epistemicmethodological focuses capable of capturing their complexity. 
Devices to understand the objects and actions that prompt the dynamics of these new time-space relations and that prompt the capture of their structuring rationales and manners of operation are therefore required. A promising possibility is the quest for learning these concepts as "relational realities", that is, as inseparable articulations between objects and human relations.

Bourdieu (2008, p. 38) warns, however, that "[...] the physical space is nothing but the empty support for the social properties of agents and institutions which, by being scattered over this surface, turned it into a socially hierarchized social space.". Such warning does not mean that, for Bourdieu (2008) space is limited to dead space (SANTOS, 2012), as noted in classic economic and geographic approaches. Likewise, it does not mean that this author will attribute to it the same status granted to the economic, social, cultural and symbolic levels. He surmises that space can only be understood in the relations that involve the ensemble of such levels. Understanding it means investigating its intersections with different mobilized capitals in a given social field. It can only be captured in its full complexity in this articulation.

Despite Bourdieu's caution regarding readings resting on environmental determinisms, an important finding of this study concerns the wealth of "spatial capital" in understanding the dynamics investigated. The prevalence of stretches with specific spatial characteristics; the greater economic and symbolic valuation of one of the sides of the street; the greater flow of people, variety of functions, mix of new and older buildings and the street block layout influencing a greater or lesser vitality of different stretches of Rua Santa Juliana suggest the active nature of the space, and also its relevance as an analytical category along the lines of economic, social, cultural and symbolic capitals. Far from neglecting the space's relational dimension, the role of the cartographic representation of the space distribution of agents and institutions investigated seems unquestionable.

The findings from Rua Santa Juliana are suggestive, because they point toward space not only as an element that transversalizes the dynamics investigated, on the contrary, it was also possible to understand it as a structuring component in the relation. Structuring to the extent that changes in its make up impact the dynamic equilibrium of the sociospatial architecture under analysis, and manifest in the articulation among the set of capitals involved.

The higher incidence of single-story homes at the beginning of Rua Santa Juliana is found, not coincidentally, in the street's area that is closest to downtown; the greater vitality of commerce in the stretch containing shorter blocks and greater contact with more densely populated neighborhoods in the buffer zone, the greater flow of dwellers, the more intense mix of older and new buildings, greater function and use diversity in addition to the prevalence of larger land lots, of newer buildings and larger businesses at the end of the street are symptomatic of the relevance of a certain spatial capital in the differentiation strategies adopted by different social agents involved with the street dynamics.

In this sense, Bourdieu's "Theory of Practical Action" methods and potentials, notably its relational, multidimensional and dimensional nature, exposed its robustness in the first extrapolation of fields and capitals originally established by the author, proving to be central to the analysis of data obtained through the Grounded Theory as regards Rua Santa Juliana. Indeed, this theory enabled the identification of similarities and differences among different capitals mobilized by its main social agents.

Concerning Jacobs (2011) theoretical perspective, empirical evidence confirms that the investigated street contemplated the four necessary conditions for the diversity and vitality of a given spatiality: function diversity, block length, mix between old and new buildings and density of people.

In theoretical terms, the relevance of these findings is once again notable upon indicating that the Rua Santa Juliana entrepreneurs show variations among them - in terms of roles played, personal attributes, management styles adopted in their businesses - and coexist 
BBR

14,3

amidst constant inter-relations, conflicts and alliances. These findings are prominent since classic literature on entrepreneurship still does not give sufficient attention to coexistence and stress dynamics among different types of entrepreneurs. In this sense, at the same time that each type of entrepreneur plays his role, pursues his objectives, mobilize different capitals and create impacts, the same coexist in a state of dynamic stress, still scantily expounded by literature on entrepreneurship.

In other words, following the path beaten by investigations pursued by Sant'Anna e Nelson (2013) and Nelson e Sant'Anna (2012), the important finding from this study is that the subjects personified in the different types of entrepreneurs identified do not emerge nor act in a social void, nor are independent from each other. On the contrary, they are a part of a community social ecology (HANNAN; FREEMAN, 1984), rife with dispute and collaboration, and with intentional and unconscious synergies as well.

Indeed, the dynamics observed on Rua Santa Juliana are quite different from the extremes that characterize traditional thinking on entrepreneurship: on the one hand, the view of entrepreneurs as almost mythical elements, who, contrarily to remaining individuals, because of their genius and unique skills were capable of identifying and enjoying opportunities and create new wealth that other could not envision (COLLINS; MOORE, 1964; MILLER, 1983; MINER, 2000; SCHUMPETER, 1950). On the other hand, the idea that macro technological and economic forces would create opportunities for new ventures, which are envisioned at random by people who happen to be at the right place at the right time, and not for their particular virtues. Examples of this line are the classic studies on Community Social Ecology (HANNAN; FREEMAN, 1984; FREEMAN; AUDIA, 2006). Unquestionably, the dynamics of Rua Santa Juliana in Sete Lagoas (MG) has forged configurations of spatial resources that are unique, to a certain extent.

Moreover, findings suggest that, albeit the types of entrepreneurs found in international literature (SMITH, 1967; FILLEY; ALDAG, 1978; COOPER; RAMACHANDRAN; SCHOORMAN, 1997; SARASVATHY, 2004; STINCHFIELD; NELSON; WOOD, 2010) can be recognized on Rua Santa Juliana, the trajectories and social origins of people who represent such types can be quite different. This indicates that, even though the types of entrepreneurs end up having a typical universal profile, the path they trek to take on a specific entrepreneur role in their field may vary significantly as a function of context.

In the same vein, in practical terms, the study contributes with elements the authors expect will provide other manners of education and development for citizens, leaders, entrepreneurs, urbanists, and public planners. In this sense, they expect to 1. Provide subsidies for the development of methods for the analysis of social entrepreneurship dynamics; 2. Present contributions for the design of methodologies for the development of leaders veered towards such processes; 3. Contribute elements for the preparation of public policies and actions oriented towards local development, incorporating more collective perspectives and resting upon the everyday operation of their agents.

As far as its limitations are concerned, notably the research framing choices, albeit fundamental to delimit a problem and allow focus upon the investigation, impose constraints and overcoming them represents research unfolding opportunities. In this sense, in the approach adopted by this study, two important choices equally correspond to two considerable limitations. The first is related to the "exploratory" nature of this study and, in this sense, to the option for a les orthodox research method, the Grounded Theory. The second concerns the conduction of its empirical part, considering a single, albeit emblematic case: the phenomenon under analysis. It would be interesting to describe and compare the study together with other cases, which is a proposition as recommendation for future investigations.

Limitations notwithstanding, the match between theory and empirical data unveil clear possibilities to respond to the research question as formulated. From the data set analyzed, 
it became evident that the different social actors involved in the Rua Santa Juliana dynamics articulate by means of different cultural, economic, symbolic and also spatial capitals. In the same manner, different diversity and vitality characteristics are associated to different manners of capital mobilization. In other words, clusters of specific social agents, mobilizing different capitals, condition and are conditioned by equally specific configurations and spatial capitals, which entail diversity- and vitality-enabling dynamics to a greater or lesser extent.

\section{REFERENCES}

AGIER, Michel. Antropologia da cidade: lugares, situações, movimentos. São Paulo: Terceiro Tempo, 2011. BAUM, Jac A. C. Ecologia organizacional. In: Clegg, Stewart . R.; Hardy, Cynthia; \& Nord, Walter R. (Eds.)

Handbook de estudos organizacionais. São Paulo: Atlas, 1998.

BOURDIEU, Pierre. Espaço físico, espaço social e espaço físico apropriado. Estudos Avançados, v. 27, n. 79, São Paulo, 2013.

BOURDIEU, Pierre. O poder simbólico. Rio de Janeiro: Bertrand Brasil, 2010.

BOURDIEU, Pierre. O senso prático. Petrópolis: Vozes, 2009.

BOURDIEU, Pierre. A distinção: crítica social do julgamento. Porto Alegre: Zouk, 2008.

BOURDIEU, Pierre. Espaço social e poder simbólico. In: BOURDIEU, Pierre. Coisas Ditas. São Paulo: Brasiliense, 2004.

BOURDIEU, Pierre. Razões práticas: sobre a teoria da ação. Campinas: Papirus, 1996.

BOURDIEU, Pierre. As regras da arte: gênese e estrutura do campo literário. São Paulo: Companhia das Letras, 1996a.

COLLINS, Orvis; MOORE, David. The enterprising man. Michigan State University Press: East Lansing, MI, 1964.

COOPER, Arnold C., RAMACHANDRAN, Mohan, \& SCHOORMAN, David F. Time Allocation Patterns of Craftsmen and Administrative Entrepreneurs: Implications for Financial Performance. Entrepreneurship theory and practice, vol. 22 (2), 123-136, 1997.

DAMATTA, Roberto1997.1. Rio de Janeiro: Rocco.. A casa e a rua: espaço, cidadania, mulher e morte no Brasil. Rio de Janeiro: Rocco, 1997.

DEY, Ian. Grounding Categories: In: Bryant. Antony Z.; \& Charmaz. Kathy T. A. (Eds.). The Sage Handbook of Grounded Theory. Sage Publications: Los Angeles, 2007.

FILLEY, Alan; ALDAG, Ramon. (1978) Characteristics and measurement of an organizational typology. Academy of Management Journal, Vol. 21(4): 578-591.

FLICK, Uwe. Introdução à pesquisa qualitativa. Porto Alegre: Editora Artmed, 2009.

FOUCAULT, Michel. O Corpo Utópico: As Heterotopias. São Paulo, n-1 Edições. 2013.

FREEMAN, John; AUDIA, Pino. Community ecology and the sociology of organizations. Annual Review of Sociology, 32: 145-169, 2006.

GLASER, Barney. Sensitivity: Advances in the methodology of grounded theory. Sociology Press: Mill Valley, CA, 1978.

GLASER, Barney. Basics of grounded theory analysis: Emergence vs. forcing. Sociology Press: Mill Valley, CA, 1992.

GLASER, Barney; STRAUSS, Aanselm. The discovery of grounded theory: Strategies for qualitative research. Aldine de Gruyter: New York, 1967.

HANNAN, Michael; FREEMAN, John. Structural inertia and organizational change. American Sociological Review, v. 49(2):149-164, 1984.

HARVEY, David. Condição Pós-Moderna. São Paulo: Edições Loyola, 1989.

JACOBS, Jane. Morte e vida de grandes cidades. São Paulo: WMF Martins Fontes, 2011.

JACOBS, Jane. The Economy of Cities. New York: Vintage, 1969.

LATOUR, Bruno. Jamais fomos modernos: ensaio de antropologia simétrica. Rio de Janeiro: Ed. 34, 1994.

LÉVI-STRAUSS, Claude. O pensamento selvagem. São Paulo: Editora Nacional, 1970.

LINCOLN, Yvonna; GUBA, Egon G. Naturalistic inquiry. London: Sage Publications, 1985.

MINTZBERG, Henry. Criando organizações eficazes: estruturas em cinco configurações. São Paulo: Atlas, 2006.

MILLER, Danny. The correlates of entrepreneurship in three types of firms. Management Science, Vol. 29(7): 770-791, 1983. 
MINER, Anne; BASSOFF, Paula; MOORMAN, Christine. Organizational improvisation and learning: A field study. Administrative Science Quarterly, v. 46: 304-337, 2001.

NELSON, Reed E.; SANT'ANNA, Anderson S. (2012) Entrepreneurial types and community dynamics in Tiradentes, Brazil. In: Academy of Management Annual Meeting. Proceedings... Boston: AoM.

RICHARDSON, Roberto J. Pesquisa social: métodos e técnicas. São Paulo: Atlas, 1985.

SÁNCHEZ, Fernanda (2003) A reinvenção das cidades: para um mercado mundial. Chapecó: Editora Argos.

SANT'ANNA, Anderson S.; NELSON, Reed E. Reconversão de funções econômicas de cidades: contribuições aos estudos sobre empreendedorismo. Pretexto, v. 14, p. 81-97, 2013.

SANTOS, Milton. O espaço dividido: Os dois circuitos da economia urbana dos países subdesenvolvidos, São Paulo: Edusp, 2014.

SANTOS, Milton. Economia Espacial: Críticas e alternativas. São Paulo: Edusp, 2014b.

SANTOS, Milton. Por uma geografia nova: Da crítica da geografia a uma geografia crítica. São Paulo: Edusp, 2012.

SARASVATHY, Sara. The questions we ask and the questions we care about: Reformulating some problems in entrepreneurship research. Journal of Business Venturing, v. 19, 2004.

SMITH, Norman R. The entrepreneur and his firm: The relationship between type of man and type of company. Michigan State University: East Lansing, MI, 1967.

STINCHFIELD, Bryan. T.; NELSON, Reed E.; WOOD, Matthew. Entrepreneurial opportunities: Bricolage, Art, Craft, engineering and Brokerage. Proceedings of the Babson Entrepreneurship Research Conference, Lausanne, Swiss, 2010.

SCHUMPETER, Joseph. Capitalism, socialism and democracy. Harper: New York, 1950.

ZALTMAN, Gerald; COULTER, Robin. Seeingthevoice of thecustomer: metaphor-basedadvertisingresearch. Journal of Advertising Research, 1995. 